$\overline{\text { Original }}$

\title{
Construction of a Consortium Comprising Ammonia-oxidizing Bacteria and Denitrifying Bacteria Isolated from Marine Sediment
}

\author{
MIYO NAKANO ${ }^{1 *}$, YASUHIRO SHIMIZU ${ }^{2}$, HIROYUKI OKUMURA ${ }^{2}$, \\ ISAWO SUGAHARA ${ }^{3}$, AND HIROTO MAEDA ${ }^{4}$ \\ ${ }^{1}$ Mie Industry and Enterprise Support Center, Core Research Laboratory, \\ Ugata 3098-9, Ago-cho, Shima, Mie 517-0501, Japan \\ ${ }^{2}$ Fisheries Research Division, Mie Prefectural Science and Technology Promotion Center, \\ Core Research Laboratory, Ugata 3098-9, Ago-cho, Shima, Mie 517-0501, Japan \\ ${ }^{3}$ Mie Technology Licensing Organization, Mie University, \\ Kurimamachiya-cho 1577, Tsu, Mie 514-8507, Japan \\ ${ }^{4}$ Marine Microbiology, Faculty of Bioresources, Mie University, \\ Kurimamachiya-cho 1577, Tsu, Mie 514-8507, Japan
}

Received 15 January, 2008/Accepted 12 April, 2008

A unique consortium of ammonia-oxidizing bacteria (AOB) and denitrifying bacteria was obtained via a long-term, 3-step cultivation of isolates from organically-enriched marine sediment. We developed this microbial consortium for possible applications in the remediation of degraded habitats in closed aquaculture or other aquatic environments via microbial degradation. Analysis of media components found definitive evidence of nitrogen removal via the coupling of ammonia-oxidation and denitrification. The phylogenetic diversity of the consortium was investigated by performing polymerase chain reaction-denaturing gradient gel electrophoresis (PCR-DGGE) that targeted the 16S rRNA gene, and the functional genes involved in ammonia-oxidation (amoA) and denitrification (nirS, nirK, norB and nosZ). Consequently, no significant divergence was observed, and thus it is suggested microbial populations were selected via a long-term, 3-step incubation process. All of the 16S rRNA clones fell into three phylogenetic groups, namely, $\gamma$-proteobacteria, Actinobacteria and Flavobacteria. For almost half of the clones, the closest relatives in the database were identified as Alcanivorax spp. and these clones were present at all cultivation stages. The presence of these species as the dominant clones is significant since these bacterial species are known to reduce nitrate to nitrite. Accordingly, their abundance in our microbial consortium may have been responsible for the observed stepwise denitrification. All sequences of the amoA gene were identified to be Nitrosomonas lineage. Half of the nirS clones were identified to be from one major group of well-known denitrifying bacteria, Pseudomonas sp. Furthermore, $70 \%$ of the nirK clones were closely related to the nirK sequences of uncultured bacterial clones isolated from arable soil. The qnorB clones consisted of clusters exclusively, and formed a distinct cluster from the novel sequences of cultivated species. The nos $Z$ clones also were not found in any of the closest relatives in the database including the uncultured bacterium from marine sediment. The unique clones obtained from the functional genes were related to each denitrification step.

Key words : Consortium/Ammonia-oxidizing bacteria/Denitrifying bacteria/Marine sediment/ PCR-DGGE.

${ }^{*}$ Corresponding author. Tel: $+81-59-232-1211$, extension

2597, Fax : +81-59-231-9540. 


\section{INTRODUCTION}

Marine aquaculture produces a large amount of effluent, which is often characterized by high concentrations of nitrogen, phosphorus and organic matter and such effluent increases the biochemical oxygen demand (BOD) and contributes to the deterioration of the water quality (Wu et al., 1995, Mazzola et al., 1999). Some substances are readily labile and undergo spontaneous degradation in the water column, but many are highly recalcitrant and accumulate in the sediment, which functions as a reservoir that continually reintroduces chemicals into the water. With the development of the aquaculture industry, efficient, cost-effective and environmentally-preserving bioremediation methods are desirable for improving the quality of effluent prior to its discharge. Microbial degradation is a potential tool for the treatment of effluent, since microbes have long been used for the effective degradation of both conventional and toxic pollutants.

Microbial nitrification and denitrification play an important role in the global nitrogen cycle, and these processes are essential for converting combined nitrogen into dinitrogen gas. In the first step of the nitrification process, chemolithoautotrophic ammoniaoxidizing bacteria $(A O B)$ are primarily responsible for the oxidation of ammonia to nitrite. Nitrification occurs aerobically and produces the substrate needed for subsequent denitrification (Casciotti et al., 2005). Denitrification, a multi-step process whereby nitrate is reduced to dinitrogen gas $\left(\mathrm{N}_{2}\right)$, is mediated by a phylogenetically diverse group of bacteria, some archaea and fungi (Zumft, W.G., 1997), and mainly occurs under anaerobic conditions. In marine environments, denitrification can eliminate more than $50 \%$ of all the nitrogen present in the oceans (Christensen et al., 1987), and it is assumed to occur on the sea floor, particularly in organic-rich continental margin sediment.

Nitrification (ammonia-oxidation) and denitrification have traditionally been considered as spatially distinct processes since the former is aerobic and the latter occurs under anaerobic conditions. Furthermore, the energy acquirement systems of $\mathrm{AOB}$ and denitrifying bacteria are quite distinct from each other. Therefore, the wastewater treatment system for nitrogen removal requires one aerobic tank and one anaerobic tank. However, the coupled processes of benthic nitrification and denitrification are generally assumed to follow a strict sequence of vertically stratified diagenetic reactions with nitrification occurring in the oxic layer of the sediment, and denitrification in the slightly lower suboxic or anoxic sediment layer (Henrilsen et al., 1988). Although these 2 processes appear to be mutually exclusive with respect to the oxygen requirements, the sharp gradients of $\mathrm{O}_{2}, \mathrm{NH}_{4}^{+}$, and $\mathrm{NO}_{3}^{-}$often present in the surface sediment enable them to occur within close proximity of each other (Hulth et al., 2005). From a practical viewpoint, these reactions should be considered to form a sequence in the $\mathrm{N}$-transforming metabolic pathway since only when both occur can bound nitrogen be completely removed from the effluent in natural environments. This study was undertaken to exploit the bacterial consortium involved in both the ammonia-oxidation and denitrification processes for possible use in the remediation of dredged habitats wherein nitrogenous materials have accumulated in the bottom sediment. As an initial step in this direction, we attempted to develop a consortium comprising both $\mathrm{AOB}$ and denitrifying bacteria via a long-term 3-step cultivation of bacteria isolated from marine sediment. PCR-DGGE analysis was applied to assess the community structure and variations in the enrichment culture.

\section{MATERIALS AND METHODS}

\section{Sampling of sediment and an enrichment culture of $A O B$ and denitrifying bacteria}

Sediment was collected at an underwater depth of $10 \mathrm{~m}$ from an organically-enriched enclosed coast located inside Ago Bay in the Mie prefecture of Japan. This organically-enriched sediment has accumulated on the sea bottom for many years as a consequence of pearl and oyster culturing. Characterization of the sediment yielded the following information for COD, acid volatile sulfides (AVS), total nitrogen ( $T-N$ ) and total organic carbon (TOC) (per g dry sediment): $55.8 \mathrm{mg} \mathrm{O}, 1.57 \mathrm{mg}, 3.77 \mathrm{mg}$ and $21.77 \mathrm{mg}$, respectively. Sediment water content and the oxidation reduction potential (ORP) value were $72.4 \%$ and $-109.3 \mathrm{mV}$, respectively (Nakanishi et al., 2001).

The procedure for the acquisition of an enrichment culture was divided into three main steps: 1) obtaining and enhancing the nitrifying bacteria; 2) activating the denitrifying bacteria; 3) starving the heterotrophs and recovering the nitrifying bacteria. The medium composition and schematic outlines for obtaining a consortium are described in Tables 1 and 2. In step 1, a sediment sample was inoculated ( $3 \%$ $\mathrm{wt} / \mathrm{vol}$ ) into a $500-\mathrm{ml}$ glass bottle containing $400 \mathrm{ml}$ of $\mathrm{Nm}$ medium (Table 1). The general medium was selected for obtaining one of the universal $\mathrm{AOB}$ members (Sato et al., 1985), and $\left(\mathrm{NH}_{4}\right)_{2} \mathrm{SO}_{4}$ at $1.5 \mathrm{~g}$ was added to enhance the ammonia-oxidation. The sample was processed on a rotary shaker at $95 \mathrm{rpm}$ in the 
TABLE 1. Composition of three types media used in this study for obtaining the consortium of $A O B$ combined with denitrifying bacteria and ANA3 medium used for analytical measurement.

\begin{tabular}{|c|c|c|c|c|}
\hline \multirow{2}{*}{$\begin{array}{l}\text { Composition } \\
\text { Medium type }\end{array}$} & \multicolumn{4}{|c|}{ Medium type } \\
\hline & $\mathrm{Nm}^{* 1}$ & $\mathrm{NiD}-\mathrm{d}^{* 1}$ & NiD-a*1 & ANA3*1 \\
\hline \multicolumn{5}{|l|}{ Artificial sea water } \\
\hline $\mathrm{NaCl}$ & $30 \mathrm{~g}$ & $5.84 \mathrm{~g}$ & $5.84 \mathrm{~g}$ & $5.84 \mathrm{~g}$ \\
\hline $\mathrm{KCl}$ & $0.7 \mathrm{~g}$ & $0.66 \mathrm{~g}$ & $0.66 \mathrm{~g}$ & $0.66 \mathrm{~g}$ \\
\hline $\mathrm{MgCl}_{2} \cdot 6 \mathrm{H}_{2} \mathrm{O}$ & $10.8 \mathrm{~g}$ & $10.8 \mathrm{~g}$ & $10.8 \mathrm{~g}$ & $10.8 \mathrm{~g}$ \\
\hline $\mathrm{MgSO}_{4} \cdot 7 \mathrm{H}_{2} \mathrm{O}$ & $5.4 \mathrm{~g}$ & $5.4 \mathrm{~g}$ & $5.4 \mathrm{~g}$ & $5.4 \mathrm{~g}$ \\
\hline $\mathrm{CaCl}_{2} \cdot 2 \mathrm{H}_{2} \mathrm{O}$ & $1 \mathrm{~g}$ & $1 \mathrm{~g}$ & $1 \mathrm{~g}$ & $1 \mathrm{~g}$ \\
\hline $\mathrm{Na}_{2} \mathrm{MoO}_{4} \cdot 2 \mathrm{H}_{2} \mathrm{O}$ & $1 \mathrm{mg}$ & & & \\
\hline $\mathrm{FeSO}_{4} \cdot 7 \mathrm{H}_{2} \mathrm{O}$ & $1 \mathrm{mg}$ & & & \\
\hline $\mathrm{MnSO}_{4} \cdot 4 \mathrm{H}_{2} \mathrm{O}$ & $1 \mathrm{mg}$ & & & \\
\hline \multicolumn{5}{|l|}{ Others } \\
\hline$\left(\mathrm{NH}_{4}\right)_{2} \mathrm{SO}_{4}$ & $1.5 \mathrm{~g}$ & $0.33 g$ & $0.33 \mathrm{~g}$ & $0.264 \mathrm{~g}$ \\
\hline $\mathrm{NaNO}_{3}$ & & & & $0.344 \mathrm{~g}$ \\
\hline carbonate buffer*2 & $10 \mathrm{ml}$ & $3 \mathrm{ml}$ & $3 \mathrm{ml}$ & $3 \mathrm{ml}$ \\
\hline phosphate buffer*2 & $10 \mathrm{ml}$ & $0.5 \mathrm{ml}$ & $0.5 \mathrm{ml}$ & $0.5 \mathrm{ml}$ \\
\hline phenol red & & & $0.5 \mathrm{mg}$ & \\
\hline phenol red solution*3 & & $1 \mathrm{ml}$ & & $1 \mathrm{ml}$ \\
\hline $\mathrm{CaCO}_{3}^{* 4}$ & $1 \mathrm{~g}$ & & & \\
\hline \multicolumn{5}{|l|}{ Trace mineral solution } \\
\hline EDTA & & $50 \mathrm{mg}$ & $50 \mathrm{mg}$ & $6 \mathrm{mg}$ \\
\hline $\mathrm{FeSO}_{4} \cdot 7 \mathrm{H}_{2} \mathrm{O}$ & & $5 \mathrm{mg}$ & $5 \mathrm{mg}$ & \\
\hline $\mathrm{FeCl}_{3} \cdot 6 \mathrm{H}_{2} \mathrm{O}$ & & & & $1 \mathrm{mg}$ \\
\hline $\mathrm{CuSO}_{4} \cdot 5 \mathrm{H}_{2} \mathrm{O}$ & & $1.6 \mathrm{mg}$ & $1.6 \mathrm{mg}$ & $4 \mu \mathrm{g}$ \\
\hline $\mathrm{MnSO}_{4} \cdot 4 \mathrm{H}_{2} \mathrm{O}$ & & $5 \mathrm{mg}$ & $5 \mathrm{mg}$ & $0.6 \mathrm{mg}$ \\
\hline$\left(\mathrm{NH}_{4}\right)_{2} \mathrm{MoO}_{24} \cdot 4 \mathrm{H}_{2} \mathrm{O}$ & & $1.1 \mathrm{mg}$ & $1.1 \mathrm{mg}$ & \\
\hline $\mathrm{Na}_{2} \mathrm{MoO}_{4} \cdot 2 \mathrm{H}_{2} \mathrm{O}$ & & & & $0.15 \mathrm{mg}$ \\
\hline $\mathrm{H}_{3} \mathrm{BO}_{3}$ & & $50 \mu \mathrm{g}$ & $50 \mu \mathrm{g}$ & \\
\hline $\mathrm{KI}$ & & $10 \mu \mathrm{g}$ & $10 \mu \mathrm{g}$ & \\
\hline $\mathrm{CoCl}_{2} \cdot 6 \mathrm{H}_{2} \mathrm{O}$ & & $50 \mu \mathrm{g}$ & $50 \mu \mathrm{g}$ & $4 \mu \mathrm{g}$ \\
\hline $\mathrm{ZnSO}_{4} \cdot 7 \mathrm{H}_{2} \mathrm{O}$ & & & & $0.3 \mathrm{mg}$ \\
\hline $\mathrm{pH}$ & $7.5-8.0$ & $7.5-8.0$ & $7.5-8.0$ & $7.5-8.0$ \\
\hline
\end{tabular}

${ }^{* 1}$ Measured per $1000 \mathrm{ml}$ distilled water.

*2 Referred to the report (Sato et al., 1985).

*3 Phenol red solution containing $25 \mathrm{mg}$ of phenol red was dissolved in $10 \mathrm{ml}$ of ethanol and $50 \mathrm{ml}$ of distilled water to detect denitrifying bacteria presented.

${ }^{* 4}$ Added for ammonia-oxidizers.

dark at $20{ }^{\circ} \mathrm{C}$, and a sillicone ${ }^{\circledR}$ (plug silicone) cap was placed at the top to make contact with oxygen. Concentrations of $\mathrm{NH}_{4}^{+}-\mathrm{N}, \mathrm{NO}_{2}^{-}-\mathrm{N}$, and $\mathrm{NO}_{3}^{-}-\mathrm{N}$ were measured every 2 weeks with a Merckoquant test strip (Merck, Germany). Each culture that met the following criteria was inoculated at $5 \%$ ( $\mathrm{vol} / \mathrm{vol})$ into a new medium and incubated 7 to 8 times repeatedly: 1) more than $40-80 \mathrm{mg} / \mathrm{l}$ of nitrite production, 2) the reduction of ammonium ions, 3) nitrate formation, and 4) the decrease in $\mathrm{pH}$. In step 2, a subculture from the first step was inoculated at 1 to $5 \%$ ( $\mathrm{vol} / \mathrm{vol}$ ) onto NiD-d medium (Table 1) at room temperature in the dark without shaking. In this step a carbon source (99.5\% ethanol) was added as a catalyst for denitrification with the phenol red $(\mathrm{pH}$ indicator) solution, which included $0.2 \mathrm{ml}$ of ethanol (Table 1). In this study ethanol was used as the carbon source, and a low $\mathrm{C} / \mathrm{N}$ ratio $(\mathrm{C} / \mathrm{N}$ ratio; 1$)$ was applied in consideration for the growth effect on $\mathrm{AOB}$ because autotrophs are vulnerable to high loads of ammonium ions and organic matter even though high $\mathrm{C} / \mathrm{N}$ ratios favor denitirifers. The incubation was continued until bubbles formed, and the color of the medium changed from pink to yellow. The concentrations of $\mathrm{NH}_{4}^{+}-\mathrm{N}, \mathrm{NO}_{2}^{-}-\mathrm{N}$, and $\mathrm{NO}_{3}^{-}-\mathrm{N}$ were also monitored. In step 3 , a subculture from the second step was inoculated at $10 \%$ (vol/vol) onto NiD-a medium (Table 1) at room temperature in the dark without shaking to recover nitrifying bacteria and starve heterotrophs. The incubation was carried out 2 to 3 times using the criteria for step 1 , and the final culture consortium yielded was then stored at $-80^{\circ} \mathrm{C}$. The frozen stock was then used according to every analytical measurement.

\section{Chemical analysis of the consortium}

To examine the activities of $\mathrm{AOB}$ combined with denitrifying bacteria in a consortium, a subculture from the third stage (step 3) was inoculated at $10 \%$ ( $\mathrm{vol} / \mathrm{vol}$ ) onto ANA3 medium (Table 1) at room temperature, in the dark and without shaking. The $\mathrm{pH}$ of the culture and the concentrations of $\mathrm{NH}_{4}{ }^{+}-\mathrm{N}_{1} \mathrm{NO}_{2}^{-}-\mathrm{N}$, $\mathrm{NO}_{3}^{-}-\mathrm{N}$ and $\mathrm{T}-\mathrm{N}$ were measured in order to monitor the ammonia-oxidation and denitrification pathway (s): the samples were harvested at 0, 7, 14, 21 and 37 days. Each sample was mixed well before being harvested, thus oxygen was newly supplied. The concentrations of $\mathrm{NH}_{4}^{+}-\mathrm{N}^{-} \mathrm{NO}_{2}^{-}-\mathrm{N}$ and $\mathrm{NO}_{3}{ }^{-} \mathrm{N}$ in the culture sample were examined using a Traacs 2000 (BRAN + LUEBBE, Norderstedt, Germany). A TOC analyzer was used for measuring T-N (an optional system installed in a TOC analyzer, TOC-Vc series, Shimadzu, Japan); $\mathrm{pH}$ was analyzed with the D-52 $\mathrm{pH}$ meter (HORIBA Ltd, Kyoto, Japan). In addition, bacterial cells were collected for subsequent DGGE.

\section{Enumeration of $A O B$ and denitrifying bacteria}

The most probable number (MPN) technique was used for enumerating $\mathrm{AOB}$ using microtitre plates (Rowe et al., 1977). The NiD-a medium without phenol red was used for the culture medium, and the $\mathrm{pH}$ was adjusted to 8.0 by adding sterile $5 \% \mathrm{Na}_{2} \mathrm{CO}_{3}$. An aliquot $(150 \mu \mathrm{l})$ of the enrichment culture, taken from the diluted serial samples, was dispensed into each well of a 96-well microtitre plate. Eight twofold serial dilutions of the enrichment culture were performed. The inoculated MPN plates were incubated in the dark for three weeks at $20{ }^{\circ} \mathrm{C}$. Following 
incubation, the wells were assayed for nitrite and nitrate by adding Griess Ilosvay reagent (GR reagent) 1 and 2 (Schmidt and Belser, 1982), and through the development of a blue colour after the addition of one or two drops of $0.2 \%$ diphenylamine in concentrated $\mathrm{H}_{2} \mathrm{SO}_{4}$ (Schmidt and Belser, 1982). They were scored as positive for ammonia oxidizers via the detection of nitrite. The presence of heterotrophic denitrifying bacteria was verified by the formation of gas inside the Durham tube and the reduction of nitrate by the GR-reagent after four weeks. One litre of nutrient broth, which consisted of $900 \mathrm{ml}$ seawater that had the same composition as the $\mathrm{Nm}$ medium (Table 1) and $100 \mathrm{ml}$ of distilled water, contained $\mathrm{NaNO}_{3}, 1 \mathrm{~g}$; yeast extract, $3 \mathrm{~g}$; and polypepton, $5 \mathrm{~g}$. Serial dilutions of the sample were prepared with sterilized seawater as the diluents. Five tubes were inoculated with decimal dilutions to $10^{-9}$, as is usual for MPN that is determined according to the standard methods for the examination of water and wastewater published by the American Public Health Association (1975).

\section{DNA extraction}

Samples $(18 \mathrm{ml})$ of the enrichment culture were harvested at $0,7,14,21$ and 37 days, and cells were collected by centrifugation $(14,000 \times \mathrm{g}$ for $5 \mathrm{~min}$ ). Bacterial cells were resuspended, rinsed with phosphate-buffered saline (PBS) buffer twice, and centri- fuged $(14,000 \times \mathrm{g}$ for $5 \mathrm{~min})$. Total genomic DNA was extracted using a G-MOME kit (BIO101, Inc. La Jolla, CA, USA) following the manufacturer's instructions.

\section{PCR amplification of 16S rRNA and the func- tional genes amoA, nirs, nirk, nor $B$, and nosZ}

To examine the change in microbial diversity and characterize the microbial community structure, samples of DNA extracted at different stages were amplified, targeting the 16S rRNA gene, and subjected to DGGE. Subsequently, a DGGE analysis of the functional diversity was performed based on the functional genes amoA, nirS, nirK, norB and nosZ, which are involved in ammonia-oxidation and each step of denitrification. The bands on the gels were cloned and sequenced, and members involved in $\mathrm{AOB}$ and denitrifying pathways were classified phylogenetically. PCR primer sequences and positions were used to amplify fragments from the 16S rRNA gene, and the functional genes of amoA, nirS, nirk, nos $Z$ and nor $B$ are shown in Table 3. PCR amplification was performed by preparing the following solution: $3 \mu \mathrm{I}$ of the DNA sample (extracted at $0,7,14$, 21 and 37 days), $0.6 \mu \mathrm{l}$ of $25 \mathrm{pmol}$ of each of the primers and $25 \mu \mathrm{l}$ of AmpliTaq gold PCR master mix (Applied Biosystems, Weiterstadt, Germany). The total volume was adjusted to $50 \mu$ I with sterile deionized water. The PCR thermocycling profile is

TABLE 2. Specifications for obtaining the consortium of $A O B$ for combination with denitrifying bacteria from marine sediment.

\begin{tabular}{|c|c|c|c|}
\hline \multirow{2}{*}{ Culture Specifications } & \multicolumn{3}{|c|}{ Incubation step } \\
\hline & Step 1 & Step 2 & Step 3 \\
\hline Media type & $\mathrm{Nm}^{* 1}$ & $\mathrm{NiD}-\mathrm{d}^{* 1}$ & $\mathrm{NiD}-\mathrm{a}^{* 1}$ \\
\hline Incubation temperature $\left({ }^{\circ} \mathrm{C}\right)$ & 20 & room temperature & room temperature \\
\hline Light/dark condition & dark & dark & dark \\
\hline Oxygen contact & $\begin{array}{l}\text { yes, with rotary shaker at } \\
\text { 95rpm via sillicone cap }\end{array}$ & no, without shaking & no, without shaking \\
\hline $\begin{array}{l}\text { Criteria for transfer to } \\
\text { new media }\end{array}$ & $\begin{array}{c}>40 \text { to } 80 \mathrm{mg} / \mathrm{I} \text { nitrite and } \\
\text { nitrate production, reduction } \\
\text { of ammonium ion }{ }^{* 2} \text { and } \\
\text { decreasing } \mathrm{pH}\end{array}$ & $\begin{array}{c}\text { added phenol red solution*1 } \\
\text { to activate denitrification, and } \\
\text { checked the concentration*2, } \\
\text { bubble formation and media } \\
\text { color change from pink to } \\
\text { yellow }\end{array}$ & $\begin{array}{l}\text { incubated until nitrite } \\
\text { production, reduction of } \\
\text { ammonium ion and } \mathrm{pH} \\
\text { decrease was observed }{ }^{* 2}\end{array}$ \\
\hline $\begin{array}{l}\text { Time interval for checking } \\
\text { the medium }\end{array}$ & 2 weeks & 2 weeks & 2 weeks \\
\hline $\begin{array}{l}\text { Frequency of transfer to } \\
\text { new medium }\end{array}$ & 7 times & once & $\begin{array}{c}\text { incubated several times and } \\
\text { stored at }-80^{\circ} \mathrm{C}\end{array}$ \\
\hline $\begin{array}{l}\text { Inoculation volume } \\
\text { transferred to new medium }\end{array}$ & $\begin{array}{c}3 \% \text { (wt/vol) with initial } \\
\text { sediment, and } 5 \% \text { (vol/vol) } \\
\text { with next step }\end{array}$ & 1 to $5 \%$ & $10 \%$ \\
\hline
\end{tabular}

${ }^{* 1}$ Refer to Table 1.

${ }^{* 2}$ Check the conc. of nitrite, nitrate and ammonium ion with commercial kit, merckoquant test strip (Merck, Germany). 
TABLE 3. Primer sequences and positions used to amplify fragments from $16 \mathrm{~S}$ rRNA, amo $A$, nir $S$, nirk, norB and nos $Z$ genes in the enrichment culture sample.

\begin{tabular}{|c|c|c|c|}
\hline Genes & Primer & Positions ${ }^{* 3}$ & Primer sequence (5'-3') \\
\hline \multirow[t]{3}{*}{ 16S rRNA*1 } & GM5F & $341-357$ & CC TAC GGG AGG CAG CAG \\
\hline & $907 \mathrm{R}$ & $907-927$ & CCG TCA ATT CCT TTG AGT TT \\
\hline & 907RA & $907-927$ & CCG TCA ATT CAT TTG AGT TT \\
\hline \multirow[t]{2}{*}{$a m o A^{* 2}$} & amoA-1F & $332-349$ & GGG GTT TCT ACT GGT GGT \\
\hline & amoA-2R & $802-822$ & CCC CTC KGS AAA GCC TTC TTC \\
\hline \multirow[t]{2}{*}{$\operatorname{nir} S^{* 2}$} & $\mathrm{~cd} 3 \mathrm{aF}$ & $916-935$ & GTR AAC GTS AAG GAR ACS GG \\
\hline & $\mathrm{R} 3 \mathrm{~cd}$ & $1322-1341$ & GAS TTC GGR TGS GTC TTG A \\
\hline \multirow[t]{2}{*}{ nirk $K^{* 2}$} & $\mathrm{FlaCu}$ & $568-584$ & ATC ATG GTS CTG CCG CG \\
\hline & $\mathrm{R} 3 \mathrm{Cu}$ & $1021-1040$ & GCC TCG ATC AGR TTG TGG TT \\
\hline \multirow[t]{2}{*}{$n o r B^{* 2}$ (qnorB) } & qnorB2 & $1204-1220$ & GGN CAY CAR GGN TAY GA \\
\hline & qnorB5 & $1466-1444$ & ACC CAN AGR TGN CAN ACC CAC CA \\
\hline \multirow[t]{2}{*}{ nor $B^{* 2}($ cnor $B)$} & cnorB2F & $553-571$ & GAC AAG NNN TAC TGG TGG T \\
\hline & cnorB6R & $942-925$ & GAA NCC CCA NAC NCC NGC \\
\hline \multirow[t]{2}{*}{$n o s Z^{* 2}$} & NosZ-F & $1169-1188$ & CGY TGT TCM TCG ACA GCC AG \\
\hline & nosZ1622R & $1603-1622$ & CGC RAS GGC AAS AAG GTS CG \\
\hline
\end{tabular}

${ }^{* 1}$ A 40-bp GC-clump (5'-CGC CCG CCG CGC GCG GCG GGC GGG GCG GGG GCA CGG GGG G-3') was added to the 5' end of the primer GM5F for separation of the DNA fragment on DGGE (Muyzer et al., 1998).

*2 A 33-bp GC-clamp (5'-GGC GGC GCG CCG CCC GCC CCG CCC CCG TCG CCC-3') was added to the reverse primer R3cd for nirS, R3Cu for nirk, and nosZ1622R for nosZ (Throback et al., 2004).

${ }^{* 3}$ Positions in the 16S rRNA of E. coli and a mixture of two reverse primers, 907R and 907RA were used, since primer 907R may not yield efficient results with some marine representatives of the $\delta$-proteobacteria due to a mismatch at the target site (Schafer et al., 2001). Positions in the amoA gene of Nitrosomonas europaea, a specific primer set for ammoniaoxidizing bacteria from the $\beta$-subdivision of the Proteobacteria, $[K=G$ or $T ; S=G$ or $C$ ] (Rhtthauwe et al., 1997). Positions in the nirS gene of Pseudomonas stutzeri Zobell ATCC 14405 (X56813), [R=A or G; $S=G$ or C]) to amplify nirS (Throback et al., 2004). Position in the nirk gene of Alcaligenes faecalis S-6 (D13155) (Hallin et al., 1999). Positions in the qnorB gene of Ra/stonia eutropha H16 (AF002661) and Paracoccus denitrificans Pd1222 (U28078), [N=A, C, G, or T; Y=C or $\mathrm{T} ; \mathrm{R}=\mathrm{A}$ or $\mathrm{G}]$ ) were used for cnorB gene. Position in the nos $Z$ gene of Pseudomonas aeruginosa DSM 50071 (X65277), $[\mathrm{Y}=\mathrm{C}$ or $\mathrm{T} ; \mathrm{M}=\mathrm{A}$ or $\mathrm{C}]$ ) was used for nos $Z$ gene (Throback et al., 2004).

TABLE 4. Summary of the PCR conditions used in this study.

\begin{tabular}{|c|c|}
\hline Primer set & Thermocycling program \\
\hline GM5F - 907R, 907RA & $\begin{array}{l}95^{\circ} \mathrm{C} \text { for } 10 \mathrm{~min} ; 10 \text { cycles of } 94^{\circ} \mathrm{C} \text { for } 1 \mathrm{~min}, 65^{\circ} \mathrm{C} \text { for } 1 \mathrm{~min} \text {, and } 72^{\circ} \mathrm{C} \text { for } 1 \mathrm{~min} ; 10 \text { cycles } \\
\text { each at annealing temperature of } 60^{\circ} \mathrm{C} \text { and } 53^{\circ} \mathrm{C} \text {; and a } 5 \text {-min final extension. }\end{array}$ \\
\hline amoA-1F - amoA-2R & $\begin{array}{l}95{ }^{\circ} \mathrm{C} \text { for } 10 \mathrm{~min} ; 35 \text { cycles of } 94{ }^{\circ} \mathrm{C} \text { for } 30 \mathrm{~s}, 57^{\circ} \mathrm{C} \text { for } 1.5 \mathrm{~min} \text {, and } 72{ }^{\circ} \mathrm{C} \text { for } 2 \mathrm{~min} \text {; and a } \\
7 \text {-min final extension. }\end{array}$ \\
\hline $\mathrm{cd} 3 \mathrm{aF}-\mathrm{R} 3 \mathrm{~cd}$ & $\begin{array}{l}95{ }^{\circ} \mathrm{C} \text { for } 10 \mathrm{~min} ; 35 \text { cycles of } 94{ }^{\circ} \mathrm{C} \text { for } 30 \mathrm{~s}, 57^{\circ} \mathrm{C} \text { for } 1.5 \mathrm{~min} \text {, and } 72{ }^{\circ} \mathrm{C} \text { for } 2 \mathrm{~min} \text {; and a } \\
7 \text {-min final extension. }\end{array}$ \\
\hline $\mathrm{FlaCu}-\mathrm{R} 3 \mathrm{Cu}$ & $\begin{array}{l}95^{\circ} \mathrm{C} \text { for } 10 \mathrm{~min} ; 35 \text { cycles of } 94{ }^{\circ} \mathrm{C} \text { for } 30 \mathrm{~s}, 57^{\circ} \mathrm{C} \text { for } 1.5 \mathrm{~min} \text {, and } 72{ }^{\circ} \mathrm{C} \text { for } 2 \mathrm{~min} \text {; and a } \\
7 \text {-min final extension. }\end{array}$ \\
\hline qnorB2 - qnorB5 & $\begin{array}{l}95{ }^{\circ} \mathrm{C} \text { for } 10 \mathrm{~min} ; 10 \text { cycles of } 94{ }^{\circ} \mathrm{C} \text { for } 30 \mathrm{~s}, 57^{\circ} \mathrm{C} \text { for } 1 \mathrm{~min} \text {, and } 72{ }^{\circ} \mathrm{C} \text { for } 1 \mathrm{~min} ; 30 \text { cycles } \\
\text { of } 94{ }^{\circ} \mathrm{C} \text { for } 30 \mathrm{~s}, 55^{\circ} \mathrm{C} \text { for } 1 \mathrm{~min} \text {, and } 72{ }^{\circ} \mathrm{C} \text { for } 1 \mathrm{~min} \text {; and a } 7 \text {-min final extension. }\end{array}$ \\
\hline nosZ-F - nosZ1622R & $\begin{array}{l}95^{\circ} \mathrm{C} \text { for } 10 \mathrm{~min} ; 13 \text { cycles of } 94{ }^{\circ} \mathrm{C} \text { for } 1 \mathrm{~min}, 63^{\circ} \mathrm{C} \text { for } 1 \mathrm{~min}, 72{ }^{\circ} \mathrm{C} \text { for } 1 \mathrm{~min} ; 13 \mathrm{cycles} \\
\text { each at an annealing temperature of } 60^{\circ} \mathrm{C} \text { and } 56{ }^{\circ} \mathrm{C} \text {; and a } 7 \text {-min final extension. }\end{array}$ \\
\hline
\end{tabular}

shown in Table 4. Amplification was performed with a Takara PCR thermal cycler MP (TaKaRa Shuzou, Shiga, Japan). Functional genes such as nirS, nirk and nos $Z$ have high sequence variation, and melting profiles obtained in WinMelt showed that all three denitrifying genes also had multiple melting domains (Throback et al., 2004). To minimize the effect of these domains and avoid the complete denaturing of the PCR-amplified fragment, a 33-bp GC-clamp was attached to the three reverse primers $\mathrm{R} 3 \mathrm{~cd}, \mathrm{R} 3 \mathrm{Cu}$ and nosZ1622R (Throback et al., 2004).

\section{DGGE profiling}

DGGE was performed as described by Muyzer et al. (1998) using a Bio-Rad DCcode universal mutation detection system (Bio-Rad Laboratories, Munich, 
Germany). A 6 to $12 \%$ polyacrylamide (acrylamide/ N, N'methilene bisacrylamide; 37.5:1) gradient was introduced together with a 20 to $60 \%$ denaturant ( $100 \%$ denaturant is $7 \mathrm{M}$ urea and $40 \%$ (vol/vol) formamide) to allow for more effective band distinction. Electrophoresis was performed at a constant voltage of $200 \mathrm{~V}$ at $61^{\circ} \mathrm{C}$ for $5 \mathrm{~h}$. The gel was then stained with SYBR Gold (Molecular Probes, Eugene, Canada) and visualized with UV transillumination. Individual excised DGGE bands were purified with a QIAEX DNA extraction kit (Qiagen, Chatworth, CA. USA) for further analysis, unless a second DGGE application was employed.

\section{Cloning, sequencing, and phylogenetic analysis}

The eluted fragments were reamplified with primers without a GC-clamp using 4-7 $\mu$ I of DNA in a total reaction volume of $55 \mu \mathrm{l}$. PCR products were ligated into a pMD18-T vector (TaKaRa Shuzou, Shiga, Japan), and subsequently transformed into JM109 competent cells. Transformed colonies were screened for inserts of the correct size by PCR amplification with the vector-specific primers M13-47 and RV-M (TaKaRa). At least four clones with the correct fragment size insert were subjected to amplification for sequencing using a TempliPhi DNA amplification kit (GE Healthcare Bio-Science Corp., NJ, USA) according to the manufacturer's instructions. Cyclesequencing reactions were conducted with an $A B I$ 310 DNA sequencer (Applied Biosystems).

Sequences were aligned with the same region of the closest relatives available using the BLAST search option of the DDBJ database (DNA Data Bank of Japan). Sequence alignments were achieved using Clustal X (Thompson et al., 1994) and a phylogenetic tree was constructed using the neighbor-joining method (Saitou and Nei, 1987). A bootstrap analysis with 1000 replicates was performed to check the robustness of the tree.

\section{Nucleotide sequence accession numbers}

The gene sequences obtained in this study have been deposited in the DDBJ nucleotide sequence database under accession no. AB261431 through AB261511.

\section{RESULTS AND DISCUSSION}

\section{Developing a bacterial consortium from marine sediment samples}

During the initial incubation step 1 (Table 2), the time intervals maintained for transferring the nitriteand nitrate-generating subcultures to new media exceeded 1 month. As the cultivation proceeded, however, we reduced the intervals. The cultivation process during step 1 counted for approximately 6 months of the project time. Overall, both nitrite and nitrate were accumulated and accompanied by a noticeable $\mathrm{pH}$ decrease during ammonia-oxidation and the subsequent nitrite-oxidation.

In step 2 (Table 2) gaseous production was initially detected at the surface of the medium, and both nitrite and nitrate immediately disappeared with the addition of a carbon source. This almost complete reduction of the total nitrogen was probably the result of the rapid conversion of bound, inorganic forms to gaseous nitrogen. The concentration and type of carbon source used may have selectively affected certain denitrifying members of the populations in step 1 of the cultivation. The decrease in $\mathrm{pH}$ (pink-to-yellow change in the medium) reflected the growth of $A O B$, suggesting that these bacteria are capable of sustaining their metabolic activity even in the presence of organic compounds. Some organic compounds have been observed to increase the growth and cell yield of $A O B$ cultured in the presence of an inorganic energy source (Krummel et al., 1982). However, the precise influence of the organic carbon source on the nitrification has not been well understood.

In step 3 (Table 2) the culture medium became less cloudy as the cultivation proceeded. The heterotrophs in the culture may have undergone stress since incubation was carried out with NiD-a medium comprising inorganic compounds. Furthermore, the second selection may have occurred among the heterotrophs and other denitrifying bacteria due to the deletion of the organic substrate. Moreover, the nitrifying bacteria could be recovered and their activity sustained.

\section{Chemical analysis of the consortium}

The subculture obtained at the end of step 3 was inoculated into ANA3 medium (Table 1) for performing analytical measurements. The ammonia and nitrate were added at an initial concentration of $4 \mathrm{mM}$ each, and these decreased after 37 days: nitrite accumulated in the ANA3 medium increased to $5.3 \mathrm{mM}$ at 37 days post-inoculation (Fig.1). The accumulation of nitrite in the medium suggests the following possibilities. (1) Nitrite-oxidizers had been lost after the second incubation step due to substrate depletion and competition for oxygen via the aerobic pathways. (2) The rapid decrease in nitrate observed during the first 7 days reflects the occurrence of denitrification and probably depended on the availability of organic carbon. This suggests that the carbon source provided was exhausted by heterotrophs competing for growth and by other denitrifying bacteria; thus no 


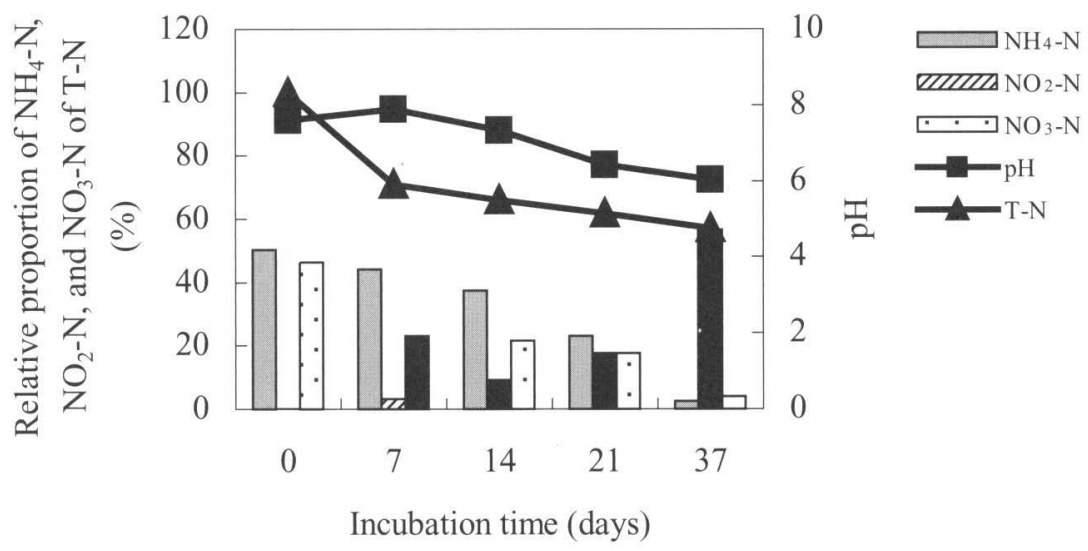

FIG. 1. Relative proportion of $\mathrm{NH}_{4}^{+}-\mathrm{N}, \mathrm{NO}_{2}^{-}-\mathrm{N}$, and $\mathrm{NO}_{3}^{-}-\mathrm{N}$ among $\mathrm{T}-\mathrm{N}$. The new culture sample was inoculated at $10 \%$ into a new ANA3 medium and incubated for 37 days. Initial concentrations of $\mathrm{NH}_{4}^{+}{ }^{-} \mathrm{N}$ and $\mathrm{NO}_{3}{ }^{-} \mathrm{N}$ added to the ANA3 medium were both $4 \mathrm{mM}$. Concentrations of $\mathrm{NH}_{4}^{+}-\mathrm{N}, \mathrm{NO}_{2}^{-}-\mathrm{N}, \mathrm{NO}_{3}^{-}-\mathrm{N}, \mathrm{T}-$ $\mathrm{N}$ and $\mathrm{pH}$ values were obtained throughout the incubation.

further nitrite reduction was observed. (3) Nitrite oxidizing activity was inhibited due to the presence of ammonia and organic carbon under the static culture conditions. The activities of both $\mathrm{AOB}$ and denitrifying bacteria were observed to vary with time; however, the $\mathrm{AOB}$ population increased from $2.5 \times 10^{4}$ (day 0 ) to $5.1 \times 10^{5}$ (day 37 ) cells $/ \mathrm{ml}$, while the denitrifying bacterial population decreased from $7.0 \times 10^{8}$ (day 0 ) to $2.0 \times 10^{8}$ (day 37 ) cells $/ \mathrm{ml}$ as measured by the most-probable-number (MPN) method.

Analytical measurements demonstrated the occurrence of the coupled processes of nitrification (ammonia-oxidation) and denitrification due to the consortium of $\mathrm{AOB}$ and denitrifying bacteria. Consequently nitrite accumulated in the medium and was not reduced further. For the process of denitrification, heterotrophic denitrifiers require organic carbon compounds such as carbohydrates, organic alcohols, amino acids, and fatty acids. In addition, denitrification rates depend on the type of carbon source. In this study, ethanol was used as carbon source; however, the impact on denitrifying bacterial growth by using a different type of carbon source was not investigated. Probably the dominant type of denitrifiers and the denitrification rate depends on the type of carbon source. In general, ethanol, methanol, and glucose are used as electron donors for denitrification in recirculating aquaculture systems (van Rijn et al., 2006). Regarding the C/N ratio, for the most readily available organic carbon source, a COD/ $/ \mathrm{NO}_{3}^{-}-\mathrm{N}(\mathrm{w} / \mathrm{w})$ ratio of 3.0-6.0 enables the complete nitrate reduction of nitrate to elemental nitrogen (Skinde and Bhagat, 1982). In this experiment the limited carbon source, a low $\mathrm{C} / \mathrm{N}$ ratio of $1.6\left(\mathrm{NH}_{4}^{+}-\mathrm{N}, 4 \mathrm{mM} ; \mathrm{NO}_{3}^{-}-\mathrm{N}, 4 \mathrm{mM}\right.$; ethanol, $\left.5 \mathrm{mM}\right)$ was employed in consideration of the effect of the growth of $A O B$ because autotrophs are vulnerable to high loads of ammonium ions and organic matter, therefore, the energy source for denitrification might be exhausted. As mentioned in a report (van Rijn et al., 2006), carbon limitation will result in the accumulation of intermediate products, such as $\mathrm{NO}_{2}$ and $\mathrm{N}_{2} \mathrm{O}$, while excess carbon will promote the dissimilatory nitrate reduction to ammonia. Recently, using the same consortium in this study, Nakahama et al. (2008) reported that the dissolved inorganic nitrogen (DIN: sum of the $\mathrm{NH}_{4}^{+}-\mathrm{N}, \mathrm{NO}_{2}^{-}-\mathrm{N}$, and $\mathrm{NO}_{3}^{-}-\mathrm{N}$ concentrations) decreased by more than 10-fold after an operation time of $126 \mathrm{~h}$ when compared with the initial value ( $\mathrm{C} / \mathrm{N}$ ratio: 10$)$. Their study revealed that this consortium could achieve almost complete nitrogen removal; furthermore, a high $\mathrm{C} / \mathrm{N}$ ratio enabled the acceleration of the nitrogen removal rate. The timing of the catalyst addition may be a key parameter for improving the efficiency of nitrogen removal without nitrite accumulation in the medium. A system wherein the nitrite produced by $\mathrm{AOB}$ can be immediately reduced by denitrifying bacteria in the presence of adequate energy could be more effective for nitrogen removal.

The reproducibility of the ammonia-oxidation/ denitrification activities in this consortium was observed when using the new, stocked inoculum for incubation. To obtain a stable partial nitrification combined with denitrification, a long-term and repeated incubation is not recommended due to the transition in the microbial components of the consortium. 


\section{DGGE for 16S rRNA fragments obtained at differ- ent culture stages}

To visualize changes in the phylogenetic diversity of the bacterial assemblage, DGGE was performed for PCR-amplified 16S rRNA fragments, derived from DNA samples that were collected from bacteria in the consortium at the different growth stages. The banding patterns obtained indicated that no remarkable changes occurred during the incubation except from days 0 to 7, although a few dissimilarities were observed among the band intensities for days 7 to 37 (Fig.2). Twelve bands were obtained on the gel (Fig.2). The structure of the microbial community of the consortium did not vary drastically during the analytical experiment in comparison with the variation derived from the chemical analysis.

In total, 29 positive clones were obtained and were found to have close relatives in the database. These clones belonged to 3 phylogenetic groups, namely, $\gamma$-proteobacteria, Actinobacteria and Flavobacteria, as shown in Fig.3. Consequently, no significant divergence was observed, suggesting that the microbial population type is selected via the long-term, 3-step incubation process. For the samples corresponding to 2 bands, $2 \mathrm{~d}$ and $2 \mathrm{~g}$, the cloning procedure was unsuccessful. For 15 clones, the closest relatives in the

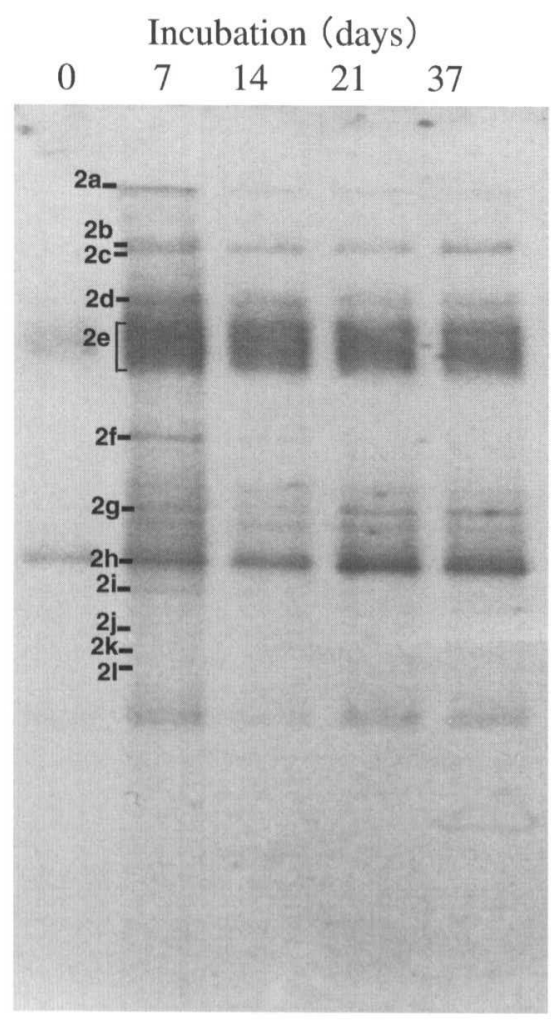

FIG. 2. DGGE profiles targeting amplified $16 \mathrm{~S}$ rRNA gene fragments at different stages of the culture enrichment. database were identified as Alcanivorax spp. and these clones were present at all cultivation stages. In addition, 11 clones were matched to Alcanivorax sp. EPR 6 (550/550, 100\% identity) that was originally isolated from a deep-sea hydrothermal vent (Vetriani et al., 2005). Clone v1 corresponding to band 2a was matched to A. dieselolei B-5 (550/550, 100 \% identity), which has recently been recognized as a novel alkane-degrading bacterium isolated from seawater and deep-sea sediment (Liu et al., 2005). Interestingly, they became a predominant part of the microbial community in crude oil-contaminated seawater when nitrogen and phosphorus are supplemented (Harayama et al., 1999). The presence of Alcanivorax spp. as the dominant clones was significant since these bacterial species are known to reduce nitrate to nitrite (Yakimov et al., 1998). In addition, the genomic sequence of the marine hydrocarbonoclastic bacterium A. borkumensis SK2 is reported as a type strain. Genome analysis yielded unprecedented insights into the bacterium's capacity for 1) n-alkane degradation, including metabolism, biosurfactant production and biofilm formation, 2) scavenging nutrients and cofactors in the oligotrophic marine environment and 3) coping with various habitat-specific stress factors (Schneiker et al., 2006). Furthermore, A. borkumensis SK2 expressed nnrS genes including nirk and nor (Schneiker et al., 2006), implying that the species performs nitrite and nitrate reduction sequentially.

In this experiment, three types of species, which exhibit denitrifying activities, were isolated from this consortia. Two of them were identified as belonging to Alcanivorax sp. and Pseudomonas sp. using $16 \mathrm{~S}$ rRNA analysis (data not shown). Accordingly, considering their abundance in our microbial consortium, the dominant bacteria may have been responsible for the observed nitrate and nitrite reduction. The other dominant clones were identified as Dietzia spp. These were originally isolated form coastal subseafloor sediment (Rainay et al., 1995), and belong to group Actinobacteria. Three clones, v26, v27 and v28, corresponding to band 21 which was a weak band, were identified as Vitellibacter vladivostokensis $(547 / 547,100 \%$ identity), a member of the family Flavobacteriaceae that was discovered in 2003 and that can be found in marine environments (Nedsahkovskaya et al., 2003). Band 2c represented a complex mixture beyond the genus level, as shown in Fig.3. The closest relatives of clone $v 9$ matched Pseudomonas stutzeri (532/550, $96 \%$ identity) a denitrifying bacteria belonging to the phylogenetic group $\gamma$-proteobacteria. Clone $v 8$ was included in an actinobacterial cluster and $v 7$ in the Alcanivorax sp. 


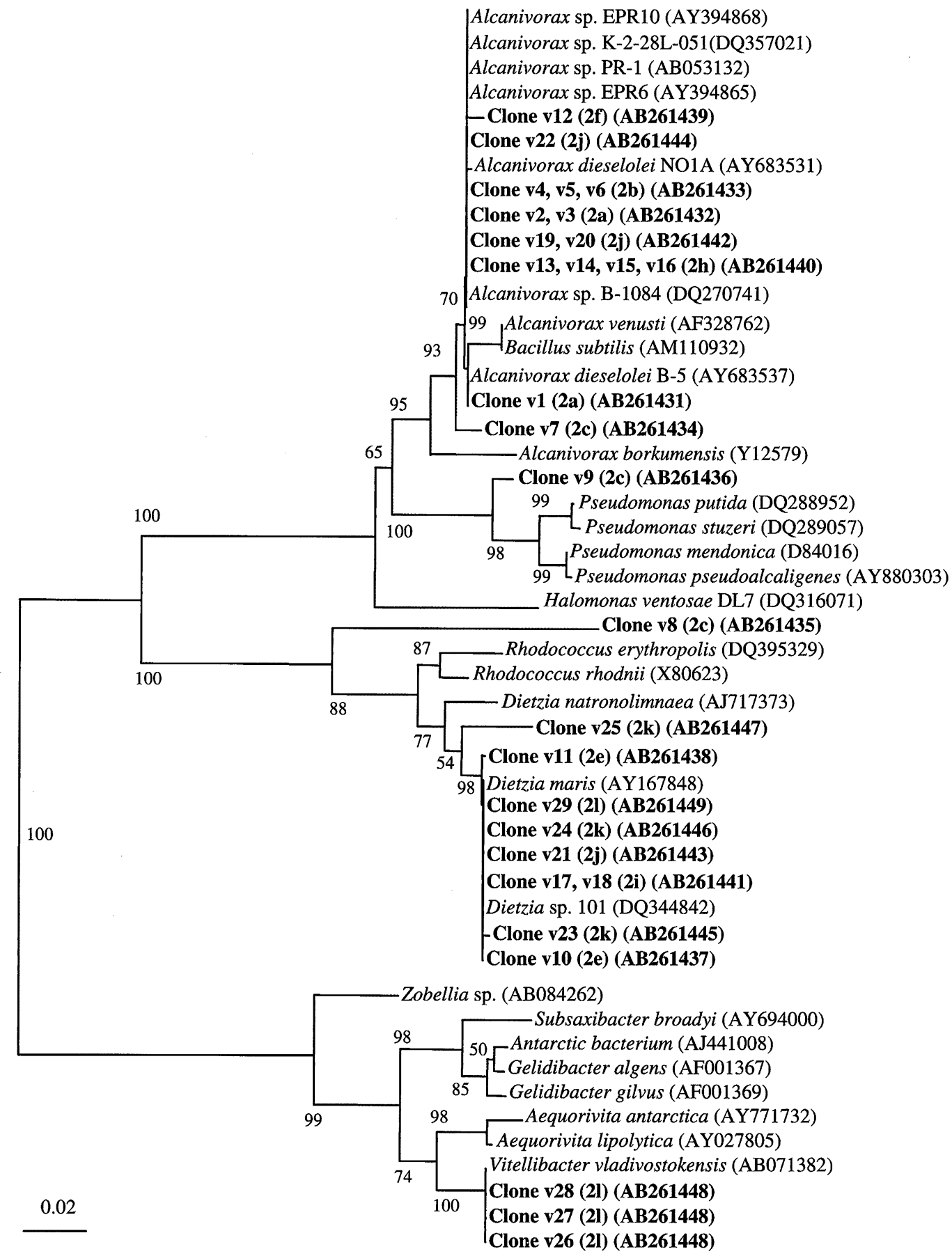

FIG. 3. Phylogenetic analysis based on partial $16 \mathrm{~S}$ rRNA gene fragments. The tree was constructed by the neighbor-joining method. The scale bar indicates $2 \%$ nucleotides substitutions. The numbers at the nodes are bootstrap confidence values expressed as percentages of 1,000 replicates: only values greater than 50 are expressed. Nucleotide sequence database accession numbers are shown in parentheses. The band number is indicated followed by the number of each clone in parentheses. The clones obtained in this study are given in bold letters.

cluster. This type of diverse assemblage can be expected in environmental samples that contain complex mixtures of microorganisms of various origins, and it would not allow discrimination among any co- migrating bands having different sequences. The performance of the cloning procedure did not improve when targeting $16 \mathrm{~S}$ rRNA genes as compared to that of functional gene analysis. 


\section{DGGE profiles of the functional gene amoA in AOB}

DGGE analysis for all the functional genes amoA, nirs, nirk, norB and nos Z performed at 0, 7, 14, 21 and 37 days post-inoculation revealed no remarkable differences in the banding patterns among the cultivation stages although some dissimilarities were obtained in the band intensity. Therefore, the DGGE variations at 37 days of incubation for $a m o A$, and at 21 days of incubation for nirS, nirk, norB and nos $Z$ were further assessed.

Seven bands were obtained on the gel (Fig.4-(a)), and the cloning efficiency was ideal for the amo $A$ gene. We then examined the sequences for 28 positive clones corresponding to those 7 bands. All the retrieved sequences were among previously published amoA sequences belonging to the $\beta$-subdivision of Proteobacteria. Almost one-third of the clones corresponding to bands a1 to a4 were identified as Nitrosomonas sp. Nm107 (453/453 bp, 100\% identity), and $50 \%$ of those corresponding to bands a 5 to a7 matched Nitrosomonas sp. Nm148 (434/452 bp,
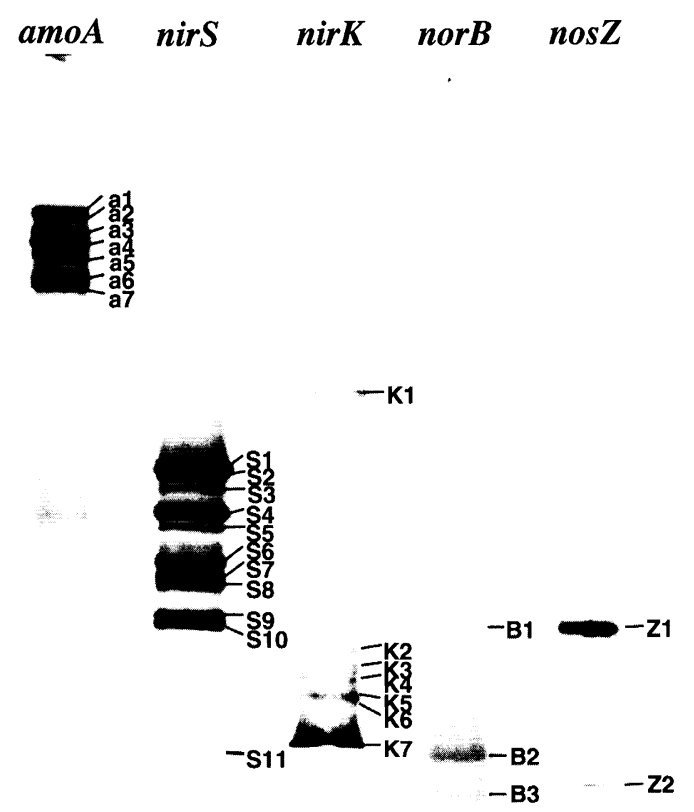
(a)
(b)
(c)
(d)
(e)

FIG. 4. DGGE profiles of dominating ammonia-oxidizers and denitrifying communities from enrichment culture samples.
$96 \%$ identity). Figure 5 illustrates a phylogenetic tree constructed based on the amoA sequence recovered from the enrichment culture as compared to certain reference sequences selected from the DDBJ database. Of 28 clones, $14(14 / 28,50 \%)$ were mutually identical and their closest pure-culture representative was Nitrosomonas nitrosa with high bootstrap values, resulting in clustering within the $N$. communis lineage. The remaining 14 clones were related to Nitrosomonas sp. strain Nm107, and exhibited mutations in several nucleotides. The findings of a previously reported $16 \mathrm{~S}$ rRNA-based phylogenetic analysis (Purkhold et al., 2000) suggest that this organism is most probably a strain of the $N$. europaeaNitrosococcus mobilis.

Nitrosomonas spp. are observed to be dominant in aquatic environments and are often found in wastewater treatment plants: this is not surprising considering the high ammonia levels often present in municipal effluent. The Nitrosomonas spp. and $N$. communis clusters that were identified in this study are often found in environments with high substrate concentrations (Koops et al., 2001). These organisms exhibit higher Ks (lower substrate affinity) values and higher growth rates than members of the genus Nitrosospiras (Pommerening-Roser et al., 1996; Scharamm et al., 2000). In this experiment, the $\mathrm{AOB}$ related to Nitrosomonas spp. were maintained in the population under high-ammonia culture conditions. The $\delta$-subclass of Proteobacteria was originally discovered in a marine environment; however, there is no evidence that these types of $A O B$ were absent. A functional gene would be a better target for fine-scale resolution with regard to the functional and ecological aspects of the microbial phylogenetic variations.

In this study, a homoduplex was produced for an amoA-based analysis of gene fragments, and several mutations were observed among the 4 clones corresponding to each band. As a speculation, these mutations could be caused by having used the degenerated primers. Another is that the $\mathrm{AOB}$ in the enrichment culture could have exhibited a point mutation in multiple copies of amoA. In a previous DGGEbased study, N. multiformis was found to yield 4 bands, whereas that of $N$. europaea yielded only a single band (Nicolaisen et al., 2002). This discrepancy may also have been due to missinterpretation and missreading of the results of the PCR and sequencing procedures. The existence of identical copies of some genes or of several mutations in certain gene sequences is not expected to have any significant effect on the melting behaviour of these genes. Mendum et al. (1999) reported that no remarkable 


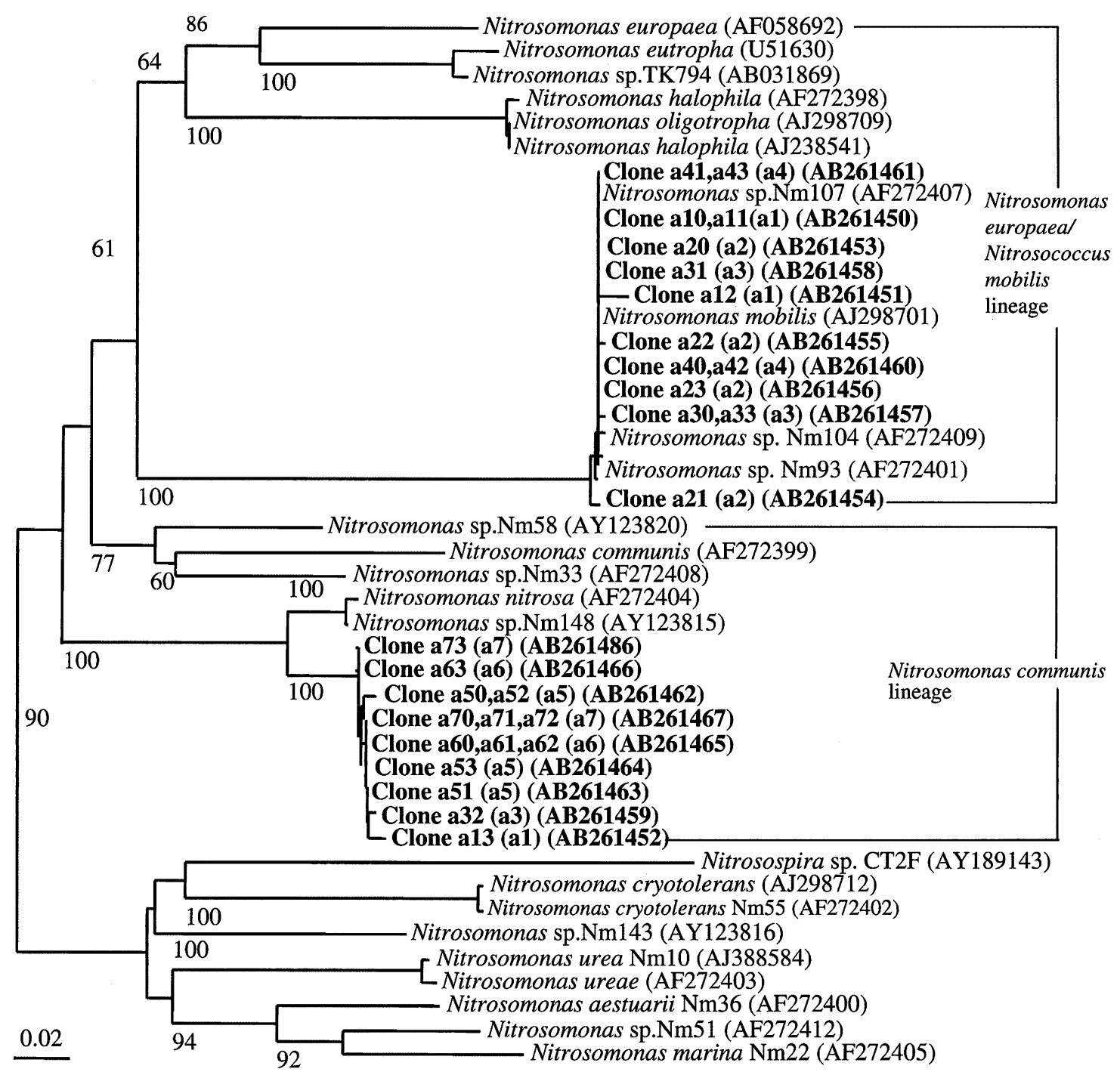

FIG. 5. Phylogenetic analysis based on partial amoA gene fragments. The tree was constructed with by the neighbor-joining method. The scale bar indicated $2 \%$ nucleotide substitutions. The numbers at the nodes are bootstrap confidence values expressed as percentages of 1,000 bootstrap replicates: only values greater than 50 are shown. Nucleotide sequence database accession numbers are shown in parentheses. The band number is indicated followed by the number of each clone in parentheses. The clones obtained in this study are given in bold letters.

changes were observed in $\mathrm{AOB}$ populations despite significant alterations in their metabolic activity. Certain transient markers, such as mRNA, can be suitable for determining particular in situ activities of microorganisms while investigating the community structure in microbial habitats.

\section{DGGE for the functional genes nirs, nirk, norB} and nos $Z$ of denitrifiers

DGGE performed for a part of the nirS gene produced a total of 11 bands for the enrichment culture samples (Fig.4-(b)). A total of 44 clones were sequenced and compared with sequences from the database; of those 22/44 (50\%) exhibited homology with the nirs gene of Pseudomonas sp. R125 (318/319, 99\% identity). In addition, all 4 clones corresponding to bands S2, S3, S5, S6 and S11 were identical, and 1 or 2 nucleotide mutations were observed among the 4 clones corresponding to the other bands. Fig.6 illustrates a phylogenetic tree based on the nirS sequence as compared to certain reference sequences selected from the database. One major cluster was observed, accompanied by a subcluster of closely related nirs sequences of Pseudomonas sp. and related isolates (cluster A). Since PCR-DGGE analysis targeting the 16S rRNA 


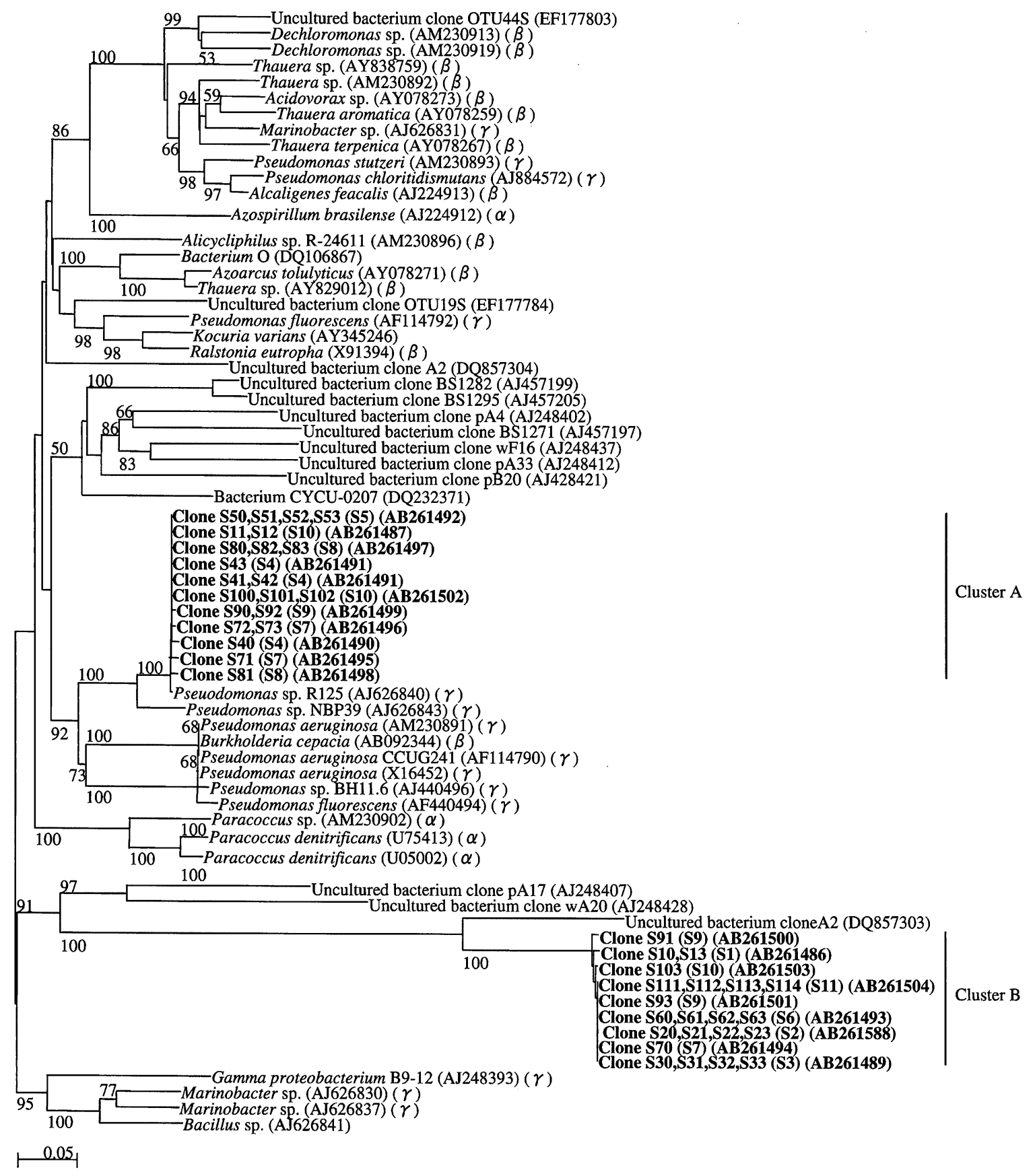

FIG. 6. Phylogenetic analysis based on partial nirS gene fragments. The tree was constructed by the neighborjoining method. The scale bar indicates $5 \%$ nucleotide substitutions. The numbers at the nodes are bootstrap confidence values expressed as percentages of 1,000 bootstrap replicates: only values greater than 50 are expressed. Nucleotide sequence database accession numbers are shown in parentheses. The band number is indicated followed by the number of each clone in parentheses. The clones obtained in this study are given in bold letters.

genes revealed clone $v 9$ to be most closely related to Pseudomonas stutzeri, we expected that the Pseudomonas sp. was involved in denitrification in the enrichment culture. Interestingly, the other subcluster comprised sequences that were very distantly related to the nirS sequences of major cultured strains (cluster B), which are closely related to the nirs genes of the uncultured bacterial clone A2 that was originally isolated from activated sludge (Geets et al., 2007). The other subcluster within this branch that included isolates from marine clones was found due to high bootstrap values (Liu et al., 2003). 
Ultimately the clones from cluster B were classified under group Proteobacteria.

DGGE performed for a part of the nirk gene by using the enrichment culture yielded a total of 7 bands (Fig.4-(c)). A total of 28 clones were sequenced and the sequences were compared with those in the data- base. The nirk gene sequences did not suggest this gene to be strongly related to any of the known nirk sequences considered in this study. Fig. 7 presents the phylogenetic tree based on the nirk sequence in the database. The major cluster (cluster A) comprised 19 of 28 clones (68\%) closely related to nirk

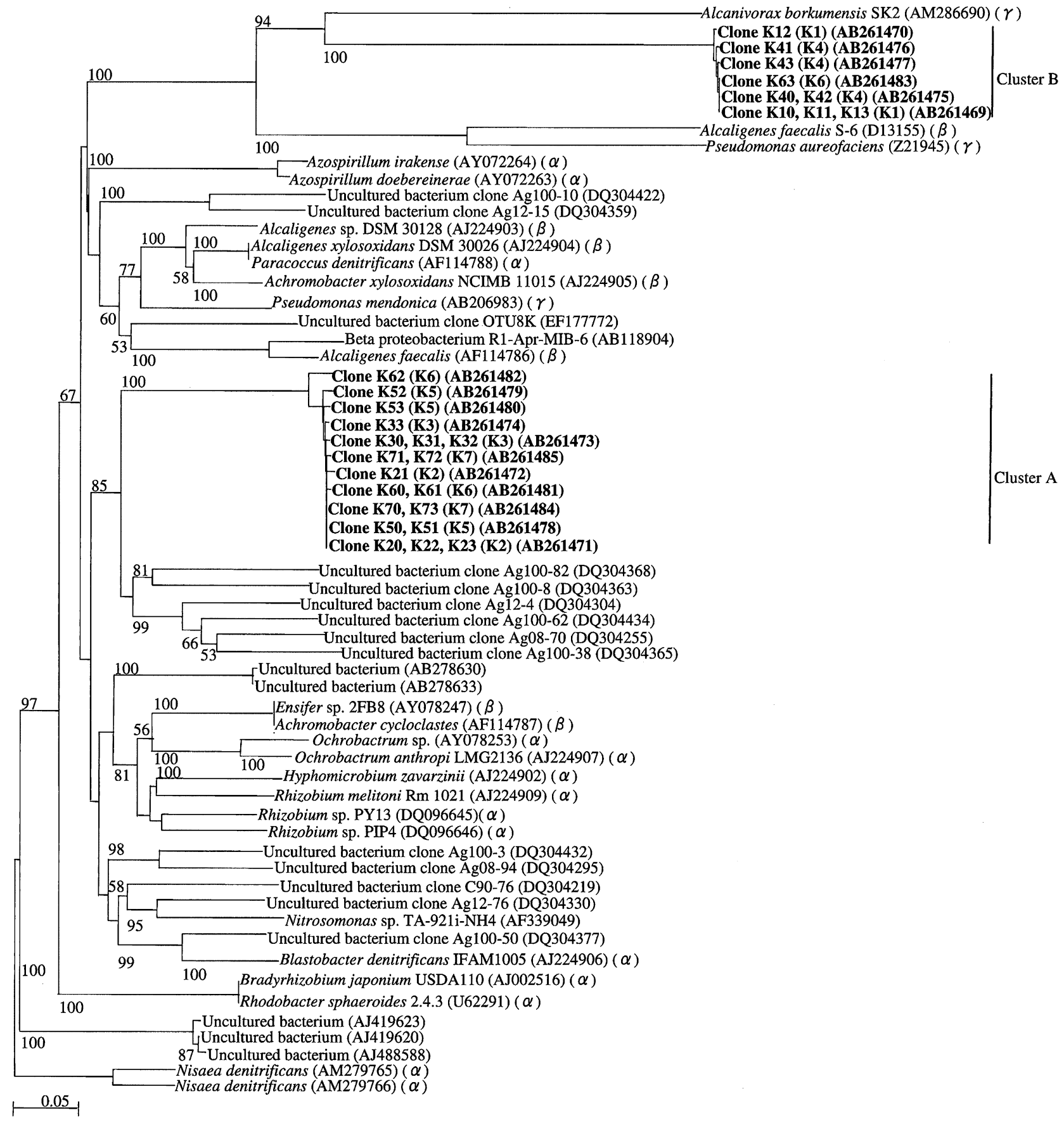

FIG. 7. Phylogenetic analysis based on partial nirk gene fragments. The tree was constructed using the neighbor-joining method. The scale bar indicates $5 \%$ nucleotide substitutions. The numbers at the nodes are bootstrap confidence values expressed as percentages of 1,000 bootstrap replicates: only values greater than 50 are shown. Nucleotide sequence database numbers are shown in parentheses. The band number is indicated followed by the number of each clone in parentheses. The clones obtained in this study are given in bold letters. 
sequences of the uncultured bacterial clone Ag100-3 with high bootstrap values (Throback et al., 2007), which has been isolated from arable soil containing the heavy metal silver. Thus, cluster A was considered the dominant clone comprising novel species of denitrifiers. The other subcluster (cluster B) comprised of 9 of 28 clones (32\%) and included the wellknown denitrifying bacteria Alcaligenes faecalis S-6 ( $\beta$-subclass), Pseudomonas aureofaciens ( $\gamma$-subclass), and Alcanivorax borkumensis SK2 ( $\gamma$-subclass). As mentioned above, PCR-DGGE analysis targeting the 16S rRNA genes of $A$. borkumensis SK2 indicated that this organism performs nitrite reduction followed by nitrate reduction. Furthermore, based on the PCR-DGGE results that more than $50 \%$ of the clones were identified as close relatives of Alcanivorax spp., it is likely that certain Alcanivorax $\mathrm{sp}$. strains in the consortium were predominantly denitrifiers. Also, these groups probably belonged to group Proteobacteria.

The molecular diversity of the nirs and nirk genes has previously been investigated to elucidate the composition and structure of denitrifying communities in the oxygen-deficient zone off the Pacific coast of Mexico. It was observed that geographic location and biochemical properties (particularly nitrate and oxygen profiles) affect the structure of denitrifying communities in marine sediment (Braker and Tiedje, 2003). In our study the high nitrate concentration, oxygen level and organic matter (ethanol concentration) throughout the cultivation period may have been responsible for the temporal changing in the microbial community composition and could be a key parameter for identifying denitrifying bacteria among the members of consortium.

In a recent report, Braker and Tiedje (2003) proposed that nor $B$ which encodes nitric oxide reductase may be used as a functional marker for investigating the distribution of denitrifying bacteria in environmental samples. One class of nor $B$ encodes the quinol-oxidizing single-subunit class (qNorB), while the other encodes a cytochrome bc-type complex (cNorB). Here, 2 primer sets were tested, namely, qnorB2F-5R targeting quinol-oxidizing nitric oxide reductase, and cnorB2F-6R targeting cytochromeoxidizing nitric oxide reductase. The PCR amplification was satisfactory with the qnorB2F-5R primer, but not with cnorB2F-6R. The partial norB genes yielded 3 bands; however the cloning results for band $B 1$ were unsatisfactory (Fig. 4-(d)). A total of 8 clones were obtained of which 5 (63\%) exhibited homology with the Alcaligenes xylosoxidans nitric oxide reductase gene norB ( $187 / 222,84 \%$ identity). Of 3 clones corresponding to band B3, 2 did not match
norB in terms of size, while the third, i.e. clone B30, did. The results of the phylogenetic analysis are shown in Fig.8. All of 5 clones that demonstrated homology with $A$. xylosoxidans were clustered within a branch of the qnor $B$ gene, corresponded to other cultured organisms including Alcaligenes sp., $A$. faecalis, A.xylosoxidans, Ralstonia eutropha, and some nondenitrifying pathogenic microorganisms such as Neisseria meningitis. In contrast to the nirS and nirk genes, anorB clones from the enrichment culture were not found to be closely related to any of environmental clones. A previous study used restriction fragment length polymorphism (RFLP) to screen a total of 130 cloned norB PCR products from sediment samples (Braker and Tiedje, 2003). The clones of the environmental qnorB genes were present on separate branches within clusters and exhibited the differences typically observed in genes from cultures versus those from natural environmental sources. Our data support the possibility that the clones obtained from the enrichment culture originated from different bacteria that were not determined to possess the qnorB gene. These clones are possibly from members of the phylum Proteobacteria.

Furthermore, the nos $Z$ gene was also not found to be very closely related to the genes in the database. DGGE produced one dense band and one weak band, i.e., $Z 1$ and $Z 2$ respectively (Fig.4-(e)). The clones obtained did not match any known nos $Z$ gene sequence (Fig.9). The 7 clones obtained were divided into 2 groups due to a high bootstrap value of 100. Both clusters were well separated from the cultured group that included the isolates from marine sediment (AF016058 and AF016059). In addition, the cluster diagram illustrated that these clones were significantly separated from the uncultured clones derived from marine sediment (AF119919, AF119944, AF119918, AF016057, AF119950, and AF119937) (Scala and Kerkhof, 1998). A possible reason for this distinct separation is that these organisms are novel denitrifiers, and were previously cultivated from marine sediment but not identified to possess the nos $Z$ gene. Scala and Kerkhof (1998) reported that the sequences of environmentally derived isolates were not closely related to those found from cultured ones and that the former exhibit substantial diversity with regard to nos $Z$, which is not true for the latter. In our study, no candidates were found in databases representing cultivated collections also in uncultured clones. These clones must also be members of Proteobacteria phylum.

A unique consortium of $\mathrm{AOB}$ and denitrifying bacteria was obtained from organic enriched marine sediment. The high nitrate concentration and organic 


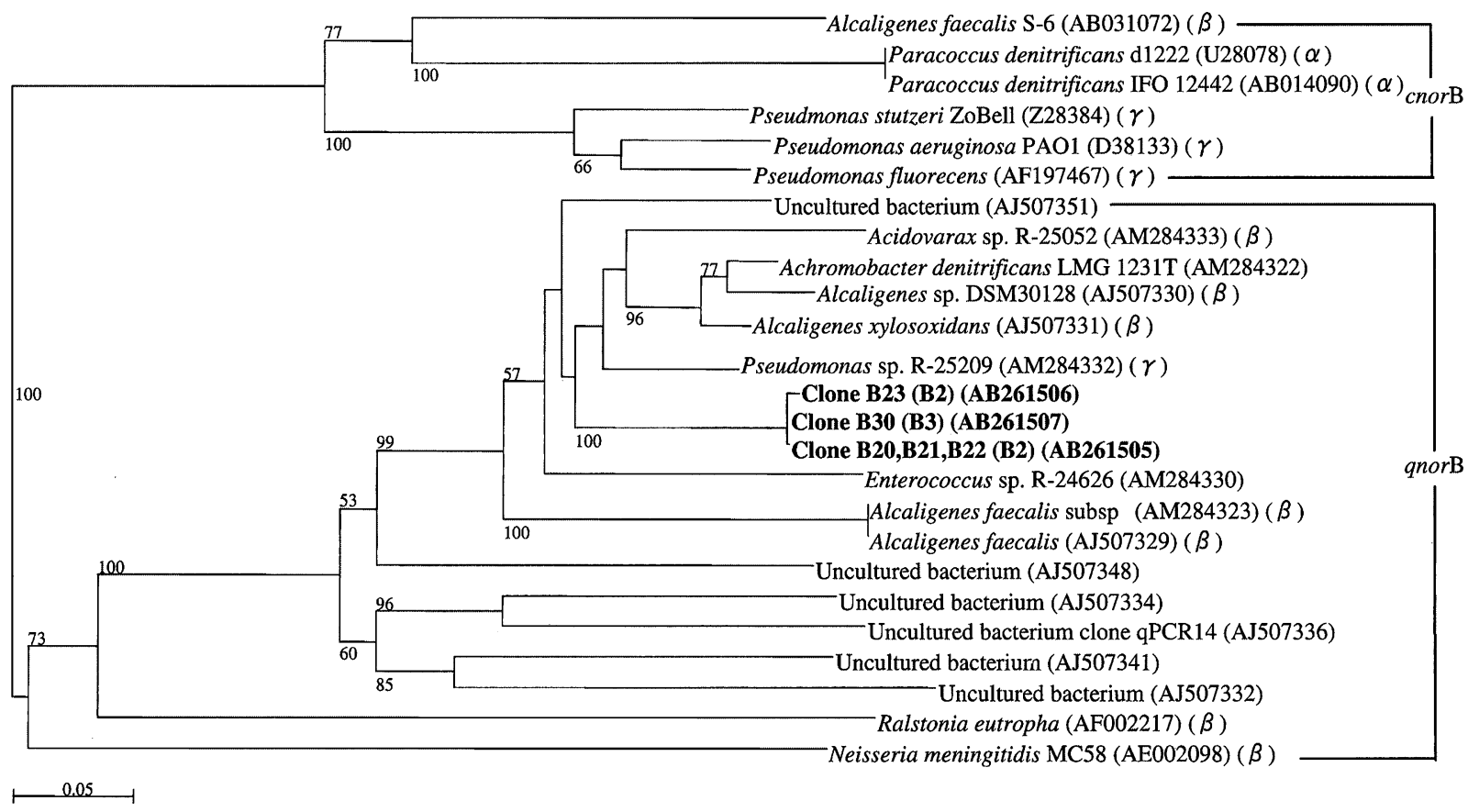

FIG. 8. Phylogenetic analysis based on partial nor $B$ gene fragments. The tree was constructed by the neighbor-joining method. The scale bar indicates $5 \%$ nucleotide substitutions. The numbers at the nodes are bootstrap confidence values expressed as percentages of 1,000 bootstrap replicates: only values greater than 50 are expressed. Nucleotide sequence database accession numbers are shown in parentheses. The band number is indicated followed by the number of each clone in parentheses. The clones obtained in this study are given in bold letters.

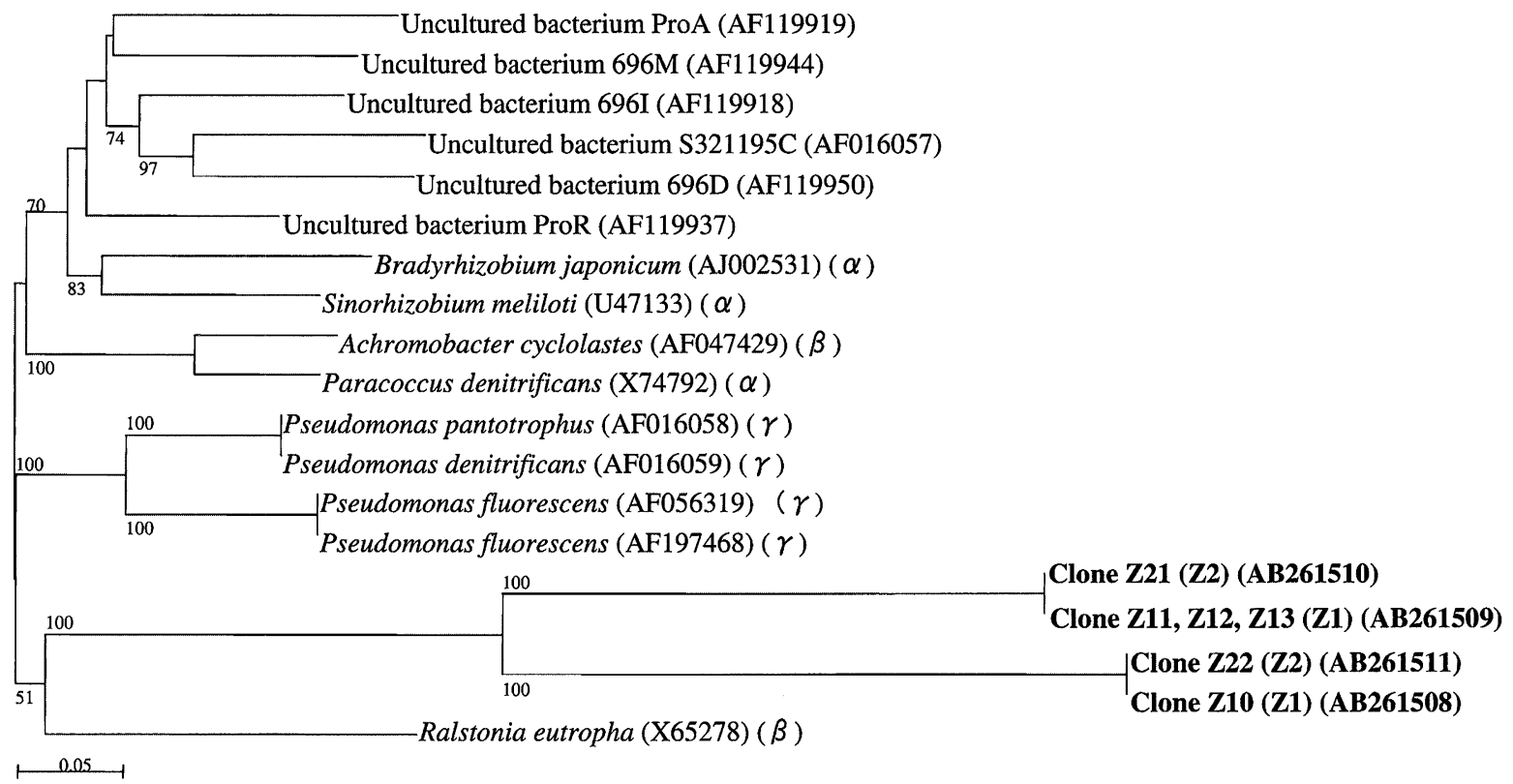

FIG. 9. Phylogenetic analysis based on partial nos $Z$ gene fragments. The tree was constructed with the neighborjoining method. The scale bar indicates $5 \%$ nucleotide substitutions. The numbers at the nodes are bootstrap confidence values expressed as percentages of 1,000 bootstrap replicates: only values greater than 50 are shown. Nucleotide sequence database accession numbers are shown in parentheses. The band number is indicated followed by the number of each clone in parentheses. The clones obtained in this study are given in bold letters. 
compounds via the cultivation procedure may have been responsible for determination in the microbial community composition. Optimizing the different environmental factors could be a key parameter for identifying the denitrifying bacteria in the consortium. The unique clones obtained from the functional genes related to each denitrification step were observed to be of the following types: 1) closely related to uncultured bacterial clones, and 2) exclusively comprising clusters of novel sequences determined for cultivated species. The data presented here provided a substantive basis for assessing the use of a bacterial consortium for the biodegradation of environmental contaminants via nitrogen removal.

\section{ACKNOWLEDGEMENTS}

This research was partly supported by the Ministry of Education, Culture, Sports, Science and Technology of Japan. The present study was performed as part of the joint collaboration research project "Environmental Project on Enclosed Coastal Seas, Ago Bay", supported by the CREATE (Collaboration of Regional Entities for the Advancement of Technological Excellence) activity program organized by the Japan Science and Technology (JST) Agency.

\section{REFERENCES}

American Public Health Association, American Water Works Association, and Water Pollution Control Federation. (1975) Standard methods for examination of water and wastewater, $14^{\text {th }}$ ed. American Public Health Association, New York.

Braker, G., and Tiedje, J.M. (2003) Nitric oxide reductase (norB) genes from pure cultures and environmental samples. Appl. Environ. Microbiol., 69, 3476-3483.

Casciotti, L.K., and Ward, B.B. (2005) Phylogenetic analysis of nitric oxide reductase gene homologues from aerobic ammonia-oxidizing bacteria. FEMS Microbiol. Ecology, 52, 197-205.

Christensen, J.P., Murray, J.W., Decal, A.H., and Codispoti, L.A. (1987) Denitrification in continental shelf sediments has major impact on the oxenic nitrogen budget. Global Biogeochem. Cycles., 1, 97-116.

Geets, J., de Cooman, M., Wittebolle, L., Heylen, K., Vanparys, B., DeVos, P., Verstraete, W., and Boon, N. (2007) Real-time PCR assay for the simultaneous quantification of nitrifying and denitrifying bacteria in activated sludge. Appl. Microbiol. Biotechnol., 75, 211-221.

Hallin, S. and Lindgren, P-E. (1999) PCR detection of genes encoding nitrite reductase in denitrifying bacteria. Appl. Environ. Microbiol., 65, 1652-1657.

Harayama, S., Kishira, H., Kasai, Y., and Shutsubo, K. (1999) Petroleium biodegradation in marine environments. J. Mol. Microbiol. Biotechnol., 1, 63-70.

Henrilsen, K. and Kemp, M. (1988) Nitrification in estuarine and coastal marine sediments. In Blabkburn, T.H., and
Sorensen, J. (Eds.), Nitrogen Cycling in Coastal Marine Environments. Wiley-Liss, New York, pp.207-273.

Hulth, S., Aller, R.C., Canfield, D.E., and Dalsgaard, T., Engstrom, P., Golbert, F., Sundback, K., Thamdrup, B. (2005) Nitrogen removal in marine environments: recent findings and future research challenges. Marine Chem., 94, 125-145.

Kisand, V. and Wikner, J. (2003) Limited resolution of $16 \mathrm{~S}$ rDNA DGGE caused by melting properties and closely related DNA sequences. J. Microbiol. Methods., 54, 183191.

Koops, H-P., and Pommerening-Roser, A. (2001) Distribution and ecophysiology of the denitrifying bacteria emphasizing cultured species. FEMS Microbiol. Ecol., 37, 1-9.

Krummel, A., and Harms, H. (1982) Effect of organic matter on growth and cell yields of ammonia-oxidizing bacteria. Arch. Microbiol., 133, 50-54.

Liu, C., and Shao, Z. (2005) Alcanivorax dieselolei sp. nov., a novel alkane-degrading bacterium isolated from sea water and deep-sea sediment Int. J. Syst. Evol. Microbiol., 55, 1181-1186.

Liu, X., Tiquia, S. M., Holguin, G., Wu, L., Nold, S. C., Devol, A. H., Luo, K., Palumbo, A. V., Tiedje, J.M., and Zhou, J. (2003) Molecular diversity of denitrifying genes in continental margin sediments within the oxygen-deficient zone off the pacific coast of Mexico. Appl. Environ. Microbiol., 69, 3549-3560

Mazzola, S., Mirto, S., and Danovaro, R. (1999) Initial fishfarm impact on meiofaunal assemblages in coastal sediments of the Western Mediterranean. Mar. pollut. Bull., 38, 1126-1133.

Mendum, T.A., Socktt, R.E., and Hirsch, P.R. (1999) Use of molecular and isotopic techniques to monitor the response of autotrophic ammonia-oxidizing populations of the $\beta$-subdivision of the class Proteobacteria in arable soils to nitrogen fertilizer. Appl. Environ. Microbiol., 65, 4155-4162.

Muyzer, G., Brinkhoff, U., Nubel, C., Sanegoeds, H., Schafer, H., and Waver, C. (1998) Denaturing gradient gel electrophoresis (DGGE) in microbial ecology. In Akkermans, A. D. L., Van Elsas, J. D. and Bruijn, F. J., (Eds.), Molecular Microbial Ecology Manual, Kluwer Academic Publishers, pp1-27.

Nakahama, K., Nakano, M., Imai, D., Dabwan, A.H.A., Kaneco, S., Suzuki, T., Katsumata, H., and Ohta, K. (2007) Nitrogen removal from seawater by ammoniaoxidizing and denitrifying bacteria immobilized on porous sintered materials form sea bottom sediments: Fundamental study. ITE Lett. New Technol. and Medicine, 8, 729-734.

Nakanishi, K., Masuda, K., Hata, N., and Yamagata, Y. (2001) Present conditions and changes in recent years in organic pollution of bottom sediments in Ago Bay. Bull. Fish. Res. Div. Mie, 10, 71-77. (in Japanese).

Nedashkovskaya, O.I., Suzuki, M., Vysotskii, M.V., and Mikhailov, V.V. (2003) Vitellibacter vladivostokensis gen. nov., sp. nov., a new member of the phylum CytophagaFlavobacterium-Bacteroides Int. J. Syst. Evol. Microbiol., 53, 1281-1286.

Nicolaisen, M.H., and Ramsing, N.B. (2002) Denaturing gradient gel electrophoresis (DGGE) approaches to study the diversity of ammonia-oxidizing bacteria. J. Microbiol. Method., 50, 189-203.

Pommerening-Roser, A., Rath, G., and Koops, H-P. (1996) Phylogenetic diversity within the genus Nitrosomonas. 
Syst. Appl. Microbiol., 19, 344-351.

Purkhold, U., Pommerening-Roser, A., Juretschko, S., Schmid, M.C., Koop, H-P., and Wagner, M. (2000) Phylogeny of all recognized species of ammonia oxidizers based on the comparative 16S rRNA and amoA sequence analysis: implications for molecular diversity surveys. Appl Environ Microbiol., 66, 5382-6368.

Rainey, F.A., Klatte, S., Kroppenstedt, R.M., and Stackebrandt E. (1995) Dietzia, a new genus including Dietzia maris comb. Nov., formerly Rhodococcus maris. Int. J. Syst. Bacteriol., 45, 32-36.

Rotthauwe, J.H., Witzel, K.P., and Liesack, W. (1997) The ammonia monooxygenase structural gene amoA as a functional marker: molecular fine-scale analysis of natural ammonia-oxidizing populations. Appl. Environ. Microbiol., 63, 4704-4712.

Rowe, R., Todd, R., and Waide, J. (1977) Microtechnique for most-probable number analysis. Appl. Environ. Microbiol., 33, 675-680.

Saitou, N., and Nei, M. (1987) The neighbor-joining method: a new method for reconstructing phylogenetic trees. Mol. Biol. Evol., 4, 406-425.

Sato, C., Schnoor, J.L., McDonald, D.B., Huey, J. (1985) Test medium for the growth of Nitrosomonas europae. Appl. Environ. Microbiol., 49, 1101-1107.

Scala, D.J. and Kerkhof, L.J. (2000) Horizontal heterogeneity of denitrifying bacterial communities in marine sediments by terminal restriction fragment length polymorphism analysis. Appl. Environ. Microbiol., 66, 1980-1986.

Scala, D.J. and Kerkhof, L.J. (1998) Nitrous oxide reductase (nos $Z$ ) gene-specific PCR primers for detection of denitrifiers and three nos $Z$ genes from marine sediments. FEMS Microbiol. Lett., 162, 61-68.

Schafer, H., Bernaed, L., Courties, C., Lebaron, P., Servais, P., Pukall, P., Stackebrandt, E., Troussellier, M., Guindulain, T., Vives-Rego, J., and Muyzer, G. (2001) Microbial community dynamics in Mediterranean nutrientenriched seawater mesocosms: changes in the genetic diversity of bacterial populations. FEMS Microbiol. Ecology., 34, 243-253.

Scharamm, A., De Beer, D., Gieseke, A., and Amann, R. (2000) Microenvironments and distribution of nitrifying bacteria in a membrane-bound biofilm. Environ. Microbiol., 2, 680-686.
Schmidt, EL., and Belser, L.W. (1982) Enumeration by most probable number. In: Methods of soil analysis, Part 2. Chemical and Microbiological Properties-Agronomy Monograph no.9, $2^{\text {nd }}$ edn. S. Segoe Rd., Madison, WI USA. pp1027-1031.

Schneiker, S., Martins dos Santos, V.AP., Bartels, D., Bekel, T., Brecht, M, Brhrmester, J., Chernilova, T.N., Denaro, R., Ferrer, M., Gertler, C., Gosemann, A., Golyshina, O.V., Kaminski, F., and other 17 authors.: Genome sequence of the ubiquitous hydrocarbon-degrading marine bacterium Alcanivorax borkumensis. Nature, Biotechnology, 24, 997-1004.

Skinde, J.R., and Bhagat, S.K. (1982) Industrial waters as carbon sources in biological denitrification. J. WPCF, 54, 370-377.

Thompson, J.D., Gibson, T.J., Plewniak, F., Jeanmougin, F., and Higgins, D.G. (1997) The ClustalX windows interface: flexible strategies for multiple sequence alignment aided by quality analysis tools. Nucleic Acids Research, 25, 4876-4882.

Throback, I.N., Johansson, M., Rosenquist, M., Pell, M., Hansson, M., and Hallin, S. (2007) Silver $\left(\mathrm{Ag}^{+}\right)$reduces denitrification and induce enrichment of novel nirK genotypes in soil. FEMS Microbiol. lett., 207, 189-194.

Throback, I.N., Enwall, K., Jarvis, A., and Hallin, S. (2004) Reassessing PCR primers targeting nirS, nirk and nosZ genes for community surveys of denitrifying bacteria with DGGE. FEMS Microbiol. Ecology, 49, 401-417.

Vetriani, C., Chew, Y.S., Miller, S.M., Yagi, J., Coombs, J. Lutz, R.A., and Barkey, T. (2005) Mercury adaptation among bacteria from a deep-sea hydrothermal vent. Appl. Environ. Microbiol., 71, 220-226.

Wu, R. (1995) The environmental impact of marine fish culture: towards a sustainable future. Mar. pollut. Bull., 31 159-166.

Yakimov, M.M., Golyshin, P.M., Lang, S., Moore, E.B., Abraham, W-R, Lunsdorf, H., and Timmis, K.N. (1998) Alcanivorax borkumensis gen. nov., sp. nov., a new, hydrocarbon-degrading and surfactant-producing marine bacterium. Int. J. Syst. Bacteriol., 48, 339-348.

Van Rijn, Tal, Y., and Schreier, H.J. (2006) Denitrification in recirculating systems: Theory and applications. Aquacult. Eng., 34, 364-376.

Zumft, W.G. (1997) Cell biology and molecular basis of denitrification. Microbiol. Mol. Biol. Rev., 61, 533-616. 